\title{
Revisiting Writer Identities in Discomforting Spaces: The Envisioned Self in Writing
}

\author{
Aditi Hunma \\ Moeain Arend \\ Gideon Nomdo \\ Catherine Hutchings \\ Sean Samson
}

\begin{abstract}
This paper explores shifts in students' writer identities in a tumultuous South African higher education context. Within the Humanities Extended Curriculum Programme, our transformation agenda triggers tensions between assimilationist and disruptive approaches to teaching writing. On our course, attempts are made to ease student's acquisition of discipline-specific writing norms, while encouraging them to draw on their brought-along resources, a negotiation causing discomfort. We invite such discomfort as productive, and ask: How do discomforting spaces inflect on our understanding of writing and writer identities? We invite students to write reflectively about how the course may or may not have influenced their identities and worldviews. Drawing on Foucault, we see the reflective essay as confessional writing, and an enactment of our writing pedagogies in discomforting spaces. We argue that in such spaces, writing can create possibilities for change, particularly as students adopt an ethical stand in their writing, calling us to reconceptualise writer identities. We apply Biko's (2017) 'envisioned self' concept to capture the ethical dimension in students' writing, by introducing a new layer of Clark and Ivanic's (1997) clover model of writer identity. Our paper contributes conceptually to existing views of writer identities, with implications for writing pedagogies in the current context.
\end{abstract}

Keywords: Writing, writer identities, writing pedagogies, confession, discomfort, reflective essays, envisioned self 


\section{Introduction}

This article revisits how writer identities get conceptualised, particularly in the politically fraught SA higher education climate, where students are using the written mode as a confession (Foucault 1990) to take a socio-political and ethical stand. This stand becomes visibilised through our pedagogy of discomfort which destabilises notions of a coherent self by introducing texts and concepts that call into question one's familiar worldviews.

The research site is a foundational academic literacy course, which has its roots in Academic Development and forms part of the Humanities ECP. As an ECP course operating within a historically white university, our primary goal is to facilitate equitable access to black students. We do this by providing epistemic access (Morrow 2009; Scott 2017) through developing students' capacity to access new knowledge in the disciplines. We complement such epistemic access with a provision of social access, derived from Mbembe's (2016:30) concept of the 'democratization of access', which goes beyond demographics to include "the possibility to inhabit a space to the extent that one can say, "This is my home. I am not a foreigner. I belong here". This is not hospitality. It is not charity'. For us as ECP lecturers (coming from disciplines such as education, sociology, and film and media), the central mission is to create opportunities for our students to experience a sense of belonging, especially since the drive to secure epistemic access can often obscure the importance of securing 'social and environmental' access, or 'access for social justice' (Wilson-Strydom 2011). For this to succeed, both forms of access are needed. We thus take seriously the ECP goals of equity and redress, using these as 'access points' to inform the theory underpinning our pedagogy.

At the same time, we are aware, on the one hand, of the tension of easing students' transition into academia through a process of assimilation, and on the other, valorising their brought along resources and encouraging them to push the frontiers of what counts as legitimate ways of knowing and writing.

Lately, we have had to reflect deeply on our roles within the highly volatile higher educational landscape, where issues of access and equity, key mobilising factors within the fallist movements (Scott 2017[a; b]), remain core concerns. Such reflective practice called for us to 'reposition' ourselves in relation to students' needs. Thus, we resorted to drawing on disciplinary dispositions to social justice, and pooled our different insights on this to develop a collaborative, context-sensitive and student-centred approach towards the teaching of academic literacy. Informing this approach is an 
ideological imperative to counter the institutional culture of stigma that continues to be attached to ECP. In 2014, we introduced a digital component comprising of weekly reflective tasks (Arend et al. 2017). In 2017, these tasks culminated in a reflective essay. Reflective writing, in particular, is one of the tools we use to work through the dilemmas encountered by our students and ourselves.

This article revisits writing and writer identities in discomforting spaces, by carefully analysing students' reflective essays as powerful confessions, and our (self) critical responses to them. We ask: How do these spaces inflect on our conceptualisation of writing and writer identities? We argue that writer identities need to be revisited to make space for an emerging identity within the current academic climate, where students' socio-political stances seek expression.

\section{The Reflective Essay}

We introduced the reflective essay into our assessment regime to encourage students to reflect on their learning. The essay is a culmination of reflective tasks assigned to students throughout the course. Prebel (2016) claims that reflective writing is 'a useful way for us to track student success or satisfaction with the course as well as the achievement of our course learning outcomes'. Our recent paper, (Samson et al. 2018), which explores students' written reflections on our course, attests to this, providing students with a 'rhetorical space to express their feelings and write about their new experiences' (Anson, in Prebel, 2016).

Drawing on Foucault (1990), the reflective essay also takes the form of a 'confession' about the students themselves, our course and writing pedagogy, and provide a means for us to think more insightfully about the nature of our teaching and the extent to which it was responsive to students' calls for transformation within the academy. This means that we have to confront the tensions, uncertainties, pain, marginalisation and resentment which many ECP students experience in their quest for acknowledgement and belonging, but also our own stories, struggles, and discomfort.

When used productively, discomfort can lead to an affirmation of self and purpose in the world, that extend well beyond the classroom. It could be imagined as the grain of sand in an oyster shell, painful but generative. As teachers of writing, this idea places the onus on us to create opportunities for 
Aditi Hunma, et al.

students to interact with this discomfort productively, by exploring how writing tasks can invite the personal as well as the ethical, into academic spaces.

\section{Literature Review \\ Writing in Discomforting Spaces}

Academic writing is seldom impersonal, and far less risk-free (Thesen \& Cooper 2014). The stakes are not only related to marks, but about what gets admitted on the page.

In such moments, writing can take the form of a calculated confession. According to Foucault (1990), historically, confessions have been used to suppress the individual to admissions of truth by regulatory powers. Thus, confessions can become a way to trigger guilt, shame and compliance (Foucault 1990). Admissions of guilt in religious contexts can lead to absolution, or varying recipes for purging, where in the legal context, they may lead to further incrimination and punishment. On our course, we are aware of how opening up confessional spaces through reflective writing can trigger moments of discomfort.

However, we explore such pedagogies for their productive potential and unpack the writer identities that are emerging in such spaces. Boler and Zembylas (2003:108) conceptualise a pedagogy of discomfort as 'an educational approach to understanding the production of norms and differences'. It seeks to make matters usually classified as personal and private - our emotional investments and beliefs - public and visible. In relation to writing, this pedagogy requires that both students and lecturers move beyond comforting certainties, expressing their challenges to these centering norms, and different ways of understanding the world.

As students engage with academic content, there are always blindspots, life-narratives to which we are oblivious, because they do not align with the social practices that anchor a secure sense of self. There is emotional labour in making a confession, as students must distance themselves from this security; from themselves so to speak. How are lecturers and students supported while engaging in the process? (Boler \& Zembylas 2003). We broach this shortly, when we examine students' reflective writing.

Importantly, rather than engaging solely with what we/ I know, and what (we/ I know) exists, this pedagogy is a deliberate attempt to engage with 
silences, using reflective writing to allow the writer to surface in her/ his writing.

A pedagogy of discomfort moves beyond the quest for a stable unitary self and embraces a notion of the self that is in process, stabilised, perhaps through different experiences, but having room for something that is presently an unknown. Definitive categories solidifying difference, are disrupted through this pedagogy of discomfort, whose goal is 'to inhabit a more ambiguous sense of self not reduced to ... binary positions ...' (Boler \& Zembylas 2003:121). The ambiguity gets enacted through the reflective tasks assigned to our students (see Nadan \& Stark 2016; MacDonald 2013).

\section{Reflective Writing as a Pedagogical Method}

The role of reflective writing as a confession that seeks to (dis)entangle the 'self that writes' and the 'self on the page' (Creme 2000) may be a starting point here. The following diagram illustrates how our writing pedagogy invites students to locate themselves in their writing and engage dialogically with their lived experiences and the concepts on the course.

The inner loop signals student engagement with the course concepts while the outer loop reflects how students draw on their lived experiences in the broader social context. These loops therefore exist in a dynamic relationship. The reflective essay illustrates this dynamism, as well as the "messiness of meaning making' (Arend et al. 2017), with opportunities to engage with concepts in a 'living way' (Butler in Zembylas 2015) in their narratives. This process of making the concepts 'real' can take students out of their comfort zones and lead to moments of tension between theory and lived reality; a gap that is not easy to suture.

Unlike the final reflective essay, the weekly reflective tasks are neither assessed, nor do they hold students accountable for the insights shared. These continual written scripts that students produce about their identity, could be seen as a 'refrain' (Deleuze \& Guattari 1980), that brings together various, and sometimes contradictory aspects of their identity construction over time. It resonates with St Pierre's (2017:3) experience: 'my refrain enabled a pause, a gathering that was also an intensity that would explode as thinking-writing picked up speed again'. The pause could be viewed as a moment of suspending 'judgement' (Arend et al. 2017), where new meaning potentials are given free rein. 


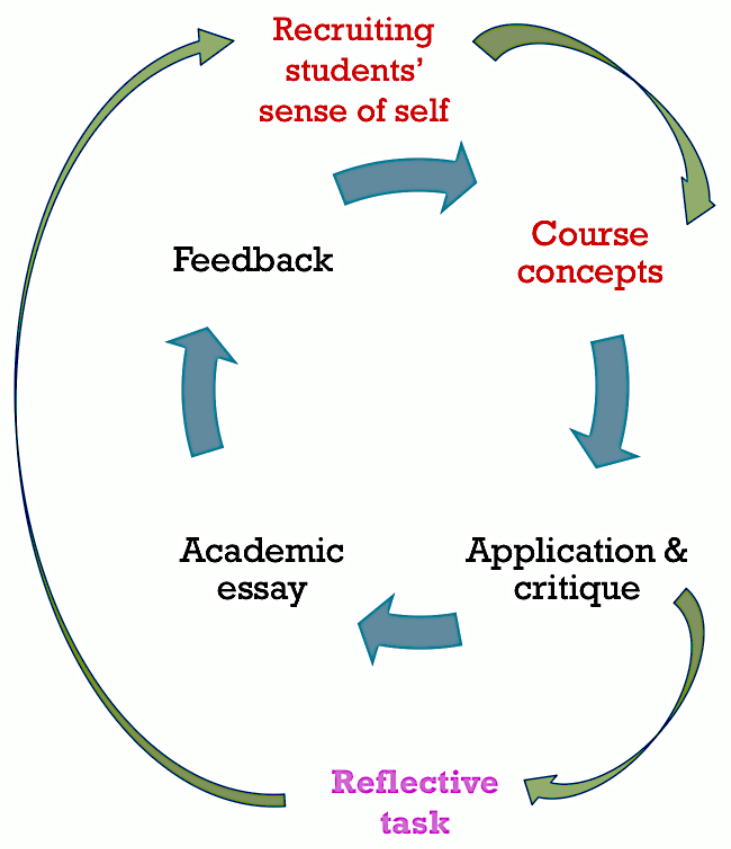

The inner-outer loop dynamic

\section{Current Understandings of Writer Identities}

Writing pedagogies designed to unleash meaning potentials, require a particular orientation that challenges the generic, skills-based approach, and aligns with the academic literacies approach where writing is inevitably agentic (Lea \& Street 1998). Thus, in the 1990s, preoccupations with the author's identity or 'voice' became central to this approach. Nonetheless, voice remained a nebulous term that could at once stand for an intrinsic and unfaltering sense of being and an acquired mode of expression. This was until Clark and Ivanic (1997) developed a framework for defining and analysing voice, which they referred to as the 'clover model of writer identities'. The clover's three leaves depict the three aspects of students' writer identities as identified in their writing, namely the 'autobiographical self': the student's life history as made evident in the text, the 'discoursal self': a discipline-specific identity, and the 'authorial self': an assertion of 'self as author'. The idea of 
authority in writing is further emphasised by Hyland (2002:1021) who notes that 'academic writing is not completely impersonal'. He explains, 'writers gain credibility by projecting an identity invested with individual authority, displaying confidence in their evaluations and commitment to their ideas'.

While conceptually the three writer identities are described as distinct elements, empirically, there are overlaps and tensions between these. For instance, in an attempt to gain insider status in the discipline, a student's deliberate attempt to conform to discipline specific conventions in writing and display the discoursal self, may at times be executed at the expense of their authorial self, where the student is expected to take ownership of ideas and shows signs of critical thinking in writing (see Hunma 2009). On the disjuncture between the autobiographical and discoursal selves, Park (2013) recounts her personal experience:

.... I reconstructed my identity as a Korean immigrant girl in the United States in the late 1970s and as a graduate student studying the experiences of diaspora. Hence, my writing became situated, social, and political in nature.

She still uses the notion of the 'autobiographical self' to describe the social and political flavour of her writing, which we feel becomes a missed opportunity to theorise more aptly the activism present in her text.

Her diasporic experience highlights the role of context in determining the possibilities for articulating voice. For Blommaert (2005), voice is a matter of 'uptake' in particular contexts or repertoires, which Clark and Ivanic (1997) describe as 'available positions for selfhood'. Matsuda (2001) goes a step further to consider 'socially available yet ever-changing repertoires'. It thus becomes evident that an expression of one's writer identities while overlooking what is permitted in particular contexts, may not readily yield the approval of academic gatekeepers.

Presently, the calls for decolonising the curriculum in the higher education context are prompting academics to rethink what they teach and how. It is possible that the uses to which students put writing, might transcend the three writer identities described by Clark and Ivanic (1997). For instance, to what extent can their framework capture students' critical deliberation about their location in the institution?

What this study seeks, is a conceptual frame to describe the type of 
Aditi Hunma, et al.

writing that questions those 'available positions', and surfaces the writer's ethical stance through writing. To explore this aspect further, we use students' reflective essays as our main object of scrutiny, taking cognisance of the discomforting spaces in which they find expression.

\section{Methodology}

We employ a case study methodology as the overarching lens to identify how the self manifests in student writing. Stake (1995) defines case study research as the 'study of the particularity and complexity of a single case, coming to understand its activity within important circumstances'. Through close engagement between researcher and participants, case study research aims to grasp what is happening in the field from the vantage point of the participants (Creswell 2013; Yin 2014). The insights gathered are co-constructed, as they adopt a reflexive stance towards interpreting the data (Creswell 2013).

In this study, reflexive interpretation is enabled as the lecturers also write their reflections alongside students' reflections.

\section{Reflective Writing as a Research Method}

St Pierre (2017) describes reflective writing in the post-qualitative sense, as a method that is 'living' because it loops upon itself, using writing to make sense of experiences retrospectively and to reconstruct these in the present. As a research method, it allowed us to keep track of our emerging insights as we inserted our subjective responses to student data collected.

Similar to St Pierre's (2017) movement between 'two capacious writing spaces', our dual engagement with students' reflective tasks for marking purposes and then for research purposes, sheds light on how we move across both moments, and the insights we gain from them. The marking process may have made us less attentive to some of the individual narratives, making them secondary to a generalised marking rubric. The research process though, seems to illuminate moments of identification with particular students' experiences on the part of the lecturer, and subsequently a theoretical distancing from them to generate emerging themes.

Our reflections alongside the students' reflective writing during the research process could be used as a method to develop a theoretical understanding of our pedagogic practices, experiences of discomfort and 
conceptualisations of writer identities in the extended curriculum context. In analysing students' writing, we adopt a descriptive, rather than prescriptive approach, allowing unexpected instantiations of the writing mode to reveal themselves. With this in mind, the heuristic described below becomes less of a starting point in our inquiry, and more the object of our scrutiny, to unravel what the tool may not adequately capture.

\section{The Clover as a Possible Heuristic}

Clark and Ivanic's (1997) 'clover model of writer identities', comprising the 'autobiographical self', the 'discoursal self' and the 'authorial self', offers a possible heuristic to describe the writer identities emerging in the students' texts.

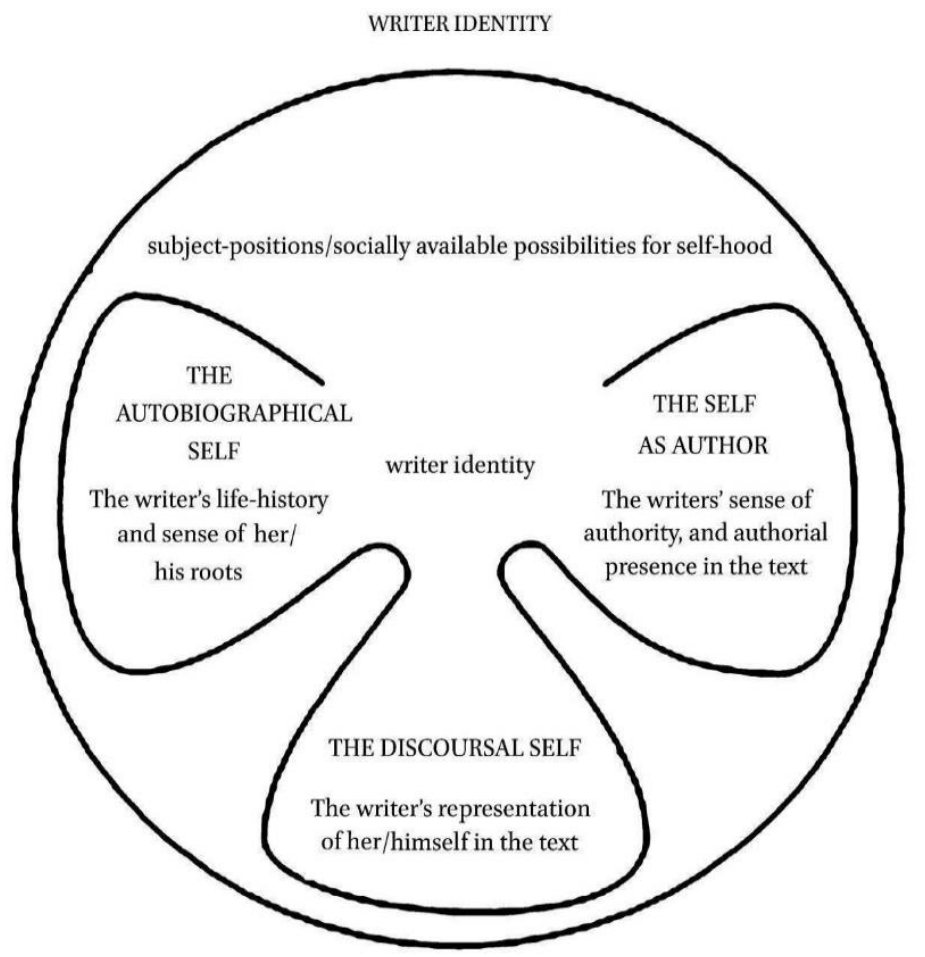

Clover model of writer identity (Clark \& Ivanič, 1997) 
Aditi Hunma, et al.

However, given the precarity of the higher education context, we open ourselves to unanticipated outcomes and put the heuristic itself to the test. The outer layer of the 'socially available possibilities for self-hood' acknowledges the 'social' possibilities alongside the 'epistemic'. However, how do we account for moments when students push the boundaries and use writing in ways that could subvert the spaces and roles available to them within these?

\section{Data Analysis}

To explore the uses to which writing is put and the reach of the clover model itself, we focus on moments of discomfort and ways in which different writer identities become apparent in our students' reflective pieces, as they seek to contain, express, challenge, and repurpose those moments. Through purposive sampling, we each selected a student from our respective classrooms who wrote reflectively about how the course may or may not have shifted their thoughts, but also their feelings and beliefs about themselves and their contexts.

The analysis that follows is inevitably tinged with the subjective experiences of the academics critically examining them.

\section{Dineo's Reflective Piece (Sean's student) ${ }^{I}$}

Discussing the work of Ngugi and problematizing his argument has opened my eyes ... our oppressors found a way to forever keep us subjugated. The best example I can use is that of the Extended Degree Programme at UCT.

... people of colour are still unable to escape the socio-economic issues that we have been dealing with since colonial powers first made their appearance.

... boundaries are no longer physical, the boundaries have become subliminal and you will only notice it if you are truly conscious.

It is epiphanies such as these that I had throughout the course and that has re-awakened an anger inside of me.

${ }^{1}$ Pseudonyms have been attributed to students mentioned in this study. 
The extract shows how the reflective task allows the student, Dineo, to be in conversation with her past identity and her present context, a conversation characterised by intellectual and emotional engagement. This eye-opening moment that Dineo refers to is used by her to critique ECP. Dineo's writing shows that she is in dialogue with her context, her placement on ECP, connecting this to a larger context of inequality, a means by which 'our oppressors found a way to forever keep us subjugated'. On the one hand, the awareness that Dineo marks the course as exemplifying ongoing inequality works to problematize Sean's position of 'comfort' as a lecturer on the course. It destabilises his sense of safety and security when considering Dineo's experiences of 'anger'. It thus takes both student and lecturer out of their comfort zones (Boler \& Zembylas 2003). But, how do we then work with this sense of discomfort?

While the experience of reflecting can be painful and result in feelings of 'anger', Dineo does have a critical and ethical awakening, an awareness of inequality that is at the heart of a pedagogy of discomfort (Boler \& Zembylas 2003), which the student describes as an 'epiphany'. This discomfort is catalysed by a critical lens which the student adopts as she grapples with the work of Kenyan author and postcolonial theorist Ngugi wa Thiongo (1987). There is a close engagement with the core text that plays a catalysing role. This critical engagement with concepts is aligned with the discoursal self (Clark \& Ivanic 1997), but one which also prompts a visceral response. In many ways then, the text signals a multi-layered conversation, as Dineo applies the theorist's work to understand and explain her experiences, a means of making sense of her thinking and feeling.

This application to experience extends the application of the discoursal self, making it real through an analysis located in the student's lived reality, one which Dineo politicises through her engagement with Ngugi, making theory 'real' in this process of application (Zembylas 2015). It is in this moment that Dineo recognises the crux of the text, a language for speaking to the ongoing material and psychological effects of the colonial system. While Dineo's critique encompasses the course itself, it signals a moment of learning and critical engagement that is an outcome of a pedagogical approach. Clearly it is through Dineo's writing that discomfort is articulated. The result is a hybrid text that does not draw distinctions between experiences of critical reading, analysis and engagement that are central to the course and a broader experience of the university. 
Aditi Hunma, et al.

Certainly, Dineo takes a stance in the text, stating clearly that 'people are still unable to escape the socio-economic issues that we have been dealing with since the colonial powers first made their appearance'. Yet, this position makes links to contexts outside the course, and it links to the process by which Dineo came to this realisation, opening her eyes. This suggests movement from a previous way of thinking, or one towards a way of describing what previously went unnamed. The reflective task embraces this process and reflects shifts from these silences towards awareness, in the writer's position and thinking process, in light of how they feel and what they have experienced. Rather than a settled authorial self (Clark \& Ivanic 1997), Dineo's writing makes these movements between concepts, experiences and contexts visible, describing how she has now become 'truly conscious', in this way resisting the construction of the writer who writes to signal a uniform self. Simply, the text brings the usual 'behind-the-scenes' engagement to light, rather than a current location as a point of departure.

Both Dineo and Sean's discomfort lead Sean to introduce other genres, which link student and lecturer. While not included in this extract, early on in the course Dineo used hip hop to discuss structural inequality. This move prompts Sean to introduce hip hop as a form of expression and knowledgemaking to illustrate the intersectional theory, one of the lenses covered in the course. Dineo acts as a reminder to Sean that he had encountered hip hop as a form of knowledge in his undergraduate career. It is in recognising what the student brings into the classroom, that Sean engages with his past self. In this way, Dineo's awakening, rooted in discomfort, and initially unsettling the repertoire of teaching tools Sean utilises, prompts a revisiting of practice. It is this revisiting and self-assessment that leads him to the broadening of texts and tools. This may signal an attempt to mitigate the violence of discomfort. Sean's response, deciding to draw on hip hop as a consequence of engaging with Dineo, works together with the act of writing itself, one of the means of engaging with the student, to move beyond violence or crisis (Zembylas 2015).

Both student and lecturer draw on multiple selves and locations. Dineo's writing signals a disruption of the stability of the text in which a position is solidified rather than showing the thinking and feeling process that led to its development. Because they cannot be neatly categorised in terms of the voices they amplify, or the spaces in which the writers locate themselves, they are heterogeneous texts (St Pierre 2017). Reflective writing, the thinking 
and uncertainty it allows for, and the heterogeneity that characterises it, is the means through which the discomfort becomes visible. Through reflective writing, we engage with that discomfort. Leaving discomfort as is, without a means to articulate the anger it harbours, could be viewed as the darker side of discomfort. But in this case, the anger results from close and critical engagement with course materials and applied to Dineo's broader context, beyond the course itself.

This written text cannot be captured solely through notions of biography, critical reading or emotion, nor by a view of writing that seeks to signal the immediacy or stability of a position. The movement between spaces, concepts and selves obstructs our ability to categorise the text in any one way. In addition, it becomes difficult to name the genre shifts witnessed in terms of the clover model, as the student takes the creative license to incorporate hip hop, a part of his identity, as a mode of expression.

\section{Linda's Reflective Piece (Gideon's student)}

When I began the first reading on identity by Woodward (2004), I took it with a grain of salt and a great deal of doubt and denial. The idea that our identity - the very essence of who we are - was nothing more than a social construct, and furthermore had to be validated by others in order to be real, was unnerving, to say the least .... As much as a big part of me wanted to hold onto the comfort of what I've always known - even if it was wrong - a much bigger part of me could no longer deny the truth as I did more of the course work and re-examined my own life .... When I finally understood what a social construct was, ... I began to see how this had affected nearly every aspect of my own life without realising it ... mental, emotional, and social boundaries. I had no idea to what extent they had been controlling my life, choices and the roles I played .... One of the big turning points for me was the McKinney (2013) reading .... feeling like outsiders and often being silenced due to their Cape Coloured accent was a situation that I was all too familiar with. It was at that specific moment that the information and concepts that I had been reading about for weeks became real. 
Aditi Hunma, et al.

As a mature, goal-directed student, Linda enters the course with selfassuredness about how the world operates and what her position is, therein. This hegemonic outlook has cemented her sense of identity, the relationships she has fostered, and how she thinks, feels, responds and interacts with those around her. In Linda's reflection, she is found oscillating (Arend et al. 2017) between the authorial, discoursal and autobiographical selves (Clark \& Ivanic, 1997). Her autobiographical self emerges as a critique of an emerging discoursal self, when she relates about her suspicions in approaching the first reading.

The cocoon which houses her sense of security, and which she carries into the class, comes to be placed under scrutiny through her interactions with theoretical concepts and classroom discussions. As her discoursal self gains prominence, she is forced to apply her new-found conceptual knowledge to her autobiographical self, setting up a critical tension between what she was comfortable with on the one hand, and the realisation of the ways in which she had been positioned and marginalised throughout her life, on the other. Through its application, she makes the theory 'real', and the outcome of this realisation is a source of discomfort and outrage for her and the seemingly stable world she inhabited.

Her 'unnerving' marks the beginning of her 'deliberate wandering' (Davis \& Shadle 2000), a process of self-reflexivity through which she confronts those beliefs that had grounded her until then, beliefs which she begins to question in light of the intensity of new ideas that had intruded her normal, everyday routines. The tension between the autobiographical and discoursal selves leaves her in a suspended state, and it is here that we see the analytical mode (Arend et al. 2017) being enacted, through the reflective writing process. Utilising this analytical mode, she could repeatedly interrogate emerging views alongside hegemonic ones she had thus far accepted without question. So Linda develops a critical dynamic between her writer identities, thereby displaying the ambiguous, contradictory and multiple nature of identity, and the discomfort that goes along with it.

What emerges from her discomfort is an awareness about the ambiguity (Boler \& Zembylas 2003) and multiplicity we all possess. The reflective writing task offers her the opportunity to confront the hegemony that had made her an accomplice in her own marginalisation. In this way the use of discomfort, as a pedagogical tool, contributes towards exposing the 'violence' (Bulhad in Tejeda et al. 2009) that had been part of how she had come to view 
herself and her location in the world. Through this pedagogy of discomfort, she comes to wrestle with those 'troubled knowledges' (Jansen in Zembylas 2015) that had restricted her sense of self and had reduced her to a one-dimensional being. The self-reflective lens she now wears allows her critical awareness about her life history and opens up new possibilities for enacting agency. What stands out here is how the discoursal and authorial identities allow her to recognise and dismantle the ties that bind her, while simultaneously revealing other possibilities for her location in the world, and how to view herself.

The way in which Linda's assertive opinions gradually took on a more tentative tone, the different ways in which she came to listen, question, and respond to the new ways of seeing that he had introduced her to, made Gideon realise how destabilising the shifts are that new learning can bring about. He also came to realise the extent of the responsibilities we bear as ECP lecturers, and how fragile relationships of trust are in teaching and learning relationships. In other words, it is the introduction, management, negotiation and contestation of discomfort that become part of the ethical practices that constitute our pursuits of social justice.

Recognising our students' discomfort means that we as lecturers also bring in our discomfort, or at the very least, are made to feel uncomfortable. This signals an important meeting point, 'a purposeful way of examining uncomfortable emotions we (and our students) might otherwise resist or deflect' (Prebel 2016). Linda's recognition of how unjust norms have bound her to a limited form of being in the world, is also the route to her enlightenment. Linda's reflection signals her active participation in her life, a meeting point of her old and new selves. Embedded in Linda's reflection are the unspoken and unacknowledged bits of reckonings that intersect and contradict each other within the dimensions of the clover model of writer identities (Clark \& Ivanic 1997). So what lies hidden below the surface? What appears to be new ways of viewing herself in relation to those around her. This is made possible by the dialogue between the three components of the clover model, and may hint at something much more than what the individual components of the model offer. Linda's experience of certainty, disillusionment, realisation, awakening, oscillating, ambiguity, multiplicity and freedom, spans across the three clover leaves, holding them in productive contention, in a suspended process of 'becoming' more than its constituent and even its combined parts. 


\section{Safia's Reflective Piece (Moeain's student)}

Coming into the DOH course, I was a small-minded 18-year-old girl, whose whole world, was about to become bigger than expected. I wish to ... share with the reader, who I was, in terms of race, gender, language and identify as for a bigger understanding of who I have become and what aspects of my mindset have changed because of theories, authors, and concepts in the DOH course ....

Being the product of a mother who was seen as 'white' and a father who was seen as 'Indian', I have always had an issue with identifying myself. Because of this, I constantly found myself being asked, 'so what are you?' Before coming into this course, the mere thought of being asked this question upset everything inside of me, and because of this, the question was often met with my unimpressed blank stare. I believe I felt this way because I did not have the knowledge required to feel any different. All I knew was that my parents, grandparents, and others had told me, for example, I was told that who I was depended on me, and only me. I now know this to not be the truth.

Safia's reflection highlights her discomfort with the 'stories' she was told about her identity in a country where race played and still plays a significant role in forging identities for people. Safia notes that being a product of a biracial parental relationship brought up identity issues for herself. Because she defied the neat race categories that the apartheid and the post-apartheid regime offered her, she mentioned that she often had to field the question as to what race she is. Moeain, on the other hand mentioned that he always had an issue with the romanticised stories he was told of his ancestry. These stories promoted certain ancestors, who were constructed as chivalric and scholarly, while deleting and hiding those who were seen as ordinary and insignificant.

Safia's reflection highlights a sense of discomfort with the stories told to her by her family members about where she came from, even before she entered the academy. The discomfort with her autobiographical self becomes more 'visible' and finds expression in writing when her story meets the theories of the academy. For example, Safia comments that due to the theories, her ideas changed. Safia's observation may signal the emergence of a discoursal self that is in the process of becoming through the reflections that emerge when the 
autobiographical encounters the theories of the academy. Moeain suggests that Safia's reflections demonstrate 'The danger of a single story' (Adichie 2009), which forms part of the course, and speaks of the possible problems and discomfort that sanitised versions of one's history or autobiographical self can create.

In Moeain's response to Safia's reflection, he draws on theory and therefore privileges his discoursal self. He notes that Dugdale's (1999) research (on talk about the intrauterine contraceptive device [ICD]), concluded that objects are always both singular and multiple rather than 'converging from multiplicity to singularity'. Because artefacts have a high degree of interpretive flexibility we often see a 'continued oscillation between singularity and multiplicity rather than a movement from oscillation to a resting-place'. Moeain amplifies Dugdale's argument by drawing on the arguments of Law (2002), who suggests that like objects, human beings have multiple versions, which often 'interfere with one another, and shuffle themselves together to make a single [version]' (Law 2002: 2-3).

Moeain proposes that Adichie (2009), Dugdale (1999), and Law's (2002) arguments underscore the conundrums that students like Safia face when in a country like SA, one story of themselves, often shaped by race classification, interferes and is shuffled together with other different stories of themselves, which suddenly becomes a possibility when theories of the academy are encountered. The reflection's focal point centres the pressures post-apartheid individuals face when their autobiographical selves are expected to find a 'resting-place' (Dugdale 1999) for their identities when they are constantly asked to classify themselves in terms of 'neat' race categories. These are pressures felt by both student and lecturer in a post-apartheid era which inherited and appropriated these race categories. Furthermore, they both highlight the effects of the nexus between constructions of brought along identities and social science theories. Moeain suggests that it is at this nexus that reflective writing can play a significant role in making sense of the oscillations of self that students experience.

When considering this meeting point of experiences and academic concepts, Moeain poses the following questions: What role could reflective writing play when we situate it at this nexus point especially in a post-apartheid SA where race still plays a significant role in constructing identities? Can reflective writing be a response to Safia's 'unimpressed blank stare' when confronted with the question 'so what are you?' Can reflective writing offer a 
Aditi Hunma, et al.

momentary 'resting-place' for the constructions of student and lecturer identities? At other times, how would one describe the self that the students oscillate to and from? Would it be characterised as 'autobiographical' in the sense of rooting, uprooting and aspiring to an imagined elsewhere?

\section{Xola's Reflective Piece (Aditi's student)}

Prior to doing [the course], I consider myself to have been a narrowminded person who looked at myself, others and society with only one eye opened. What I mean by this is that I was biased about social issues and lacked understanding about the important concept of identify, my own and that of others.

The course has made me conscious of the aspect of political and social constructs in identify formation and change and given me the analytical skills to better understand the concepts of race and gender to name a few. Additionally, I did not know that these concepts are heterogeneous. I did not know that these concepts require a sense of choice. I thought it was right for society to choose for a person the cultural resources one can have access to.

Coming from a small rural village in East London called Kwamagqukela, I held essentialist views about race and gender due to the way I was socialised. Most of the people in my community hold essentialist views of social concepts and I was expected to perform my role as a young Xhosa man without question, which I did.

Xola's discomfort and guilt arise from him viewing his earlier self through the prism of identity theories. He confesses that his previous self was 'narrowminded', with 'one eye opened'. In this, he exacts symbolic violence (Zembylas 2015) upon himself and his community, as he eschews the previous 'essentialist' views passed down by his community as negative and limited. Aditi questions whether the task prompted this student to look at himself differently with the awareness of being watched. This question signals that there is a degree of voyeurism involved in reading and evaluating students' reflective tasks, which could have altered the submitted product itself. It also points to the fact that stories of the 'autobiographical self' are seldom neutral, but have a dialogical nature, being told and retold differently, depending on the audience. 
Aditi's discomfort surfaces from Xola's guilt, induced by his perception that his community's teachings do not measure up to new academic theories. It also arises more broadly from the dilemmas implicated in ECP and the lecturer's role within it. In line with the ECP goal of easing students' transition into university, are we engaging in the business of education as conversion, or opening avenues for contestation? Reflective tasks such as these may push one to ask discomforting questions about one's being and positionality, prompting one to challenge some dominant or polarised views about sociological concepts. Arguably then, a pedagogy of discomfort could promote certain social justice goals. Yet, we need to guard ourselves against the likelihood of appearing to advocate the facile abandonment of previous dominant views for new ones within the higher education context.

The question about Aditi's possible complicity in the student's assimilation remains unanswered, since students did not read our lecturers' reflective responses. This missed opportunity for reciprocity, or more specifically, 'strategic empathy', may occasion some form of 'ethical violence' (Butler in Zembylas 2015), since Xola's admission, and possible guilt and vulnerability are left unaddressed. In this case though, Xola finds comfort in the new theories that give him 'a language' to express the inexpressible.

Thus, in Xola's writing style, we find a heavy reliance on theoretical concepts, to the extent that his 'autobiographical self' when he speaks about his 'one eyed view', gets interrupted by a strong 'discoursal self' when he gets introduced to the 'political and social constructs of identity'. Though the reflective genre could allow for 'asides' (St Pierre 2017), the fact that the discoursal self gradually supplants the autobiographical self, could possibly suggest the student's attempt at appearing scholarly to gain more credibility within the academic space, where theoretical engagement tends to be valued more than narrative or anecdotal retellings.

Xola's reflective piece also sheds light on the multiple uses to which writing is put. Besides enabling the application of concepts, it has a visceral effect in making Xola interrogate his very being, his brought-along norms and practices through an interplay of the academic and reflective writing genres. However, it does more, by pushing him to a point where he starts rethinking himself anew and questioning his alliances. Here, we find the 'think-write-be' nexus play out, as an extension of St Pierre's (2017) 'think-write' mode of text production. This also bears implications for the clover model in gauging the transformative potential of writing in discomforting spaces. 


\section{Emerging Themes \\ The Layers of Dialogue}

The final reflective essays could be seen as a dialogue with the self which give legitimacy to the reflective asides that students engaged in weekly. It also makes manifest the workings of a pedagogy of discomfort, crystalising and stabilising the conflicting thoughts in the classroom in particular points in time. Students' confessions reveal how they experienced discomfort as they sought to reconcile their brought-along views with those introduced. Yet, it also invited them to occupy a discursive gap where knowledge could be appropriated, re-purposed and made more relevant. Discomfort also came from having to admit the shifts that took place in the thoughts, feelings and beliefs as expressed in students' reflective essays. These allowed students to trace critical moments in their identity formation. The act of engaging with students through meaningful dialogue underscored the productive manner in which discomfort could be dealt with. Dialogue here came to represent an enabling and empowering device, for both lecturer and student. By entering into a dialogue, we made the invisible visible. We encountered students' (as well as our own) capital, anxieties, anger, pain, resilience, aspirations and affirmations of self. It enabled us to say to each other, 'I see you' (Fraser 2005).

Dialogue allowed us to reflect on what we brought to the debate, to think about our own positionality, so that our students and ourselves walked away with something meaningful (even if it is discomforting). Lecturers experienced discomfort as they began to empathise with some of the students' discomfort. This prompted lecturers to trace critical moments in their political and professional identities. It also generated productive moments for us to revisit our pedagogical practices and examine possible contradictions between our ideals, praxis and the degree of institutional flexibility to initiate new pedagogical experiments.

\section{Revisiting Writing as a Confession}

While triggering self-dialogue, writing also occasioned moments of detachment and confession. As mentioned, confession in the traditional sense, has been used as a compliance mechanism through a process of (self) blame, guilt, remorse and absolution (Foucault 1990). However, confession is a double-edged sword. Foucault (1984) notes that confessions can also become a practice of freedom, enabling the individual to re-narrate and transform 
him/herself. What about the confessions made through the mode of academic writing?

Earlier, Foucault (1983) described a concept he came to call selfwriting, which he saw as a way of transforming what we 'see and hear into flesh and blood'. The potency of texts here to metamorphosise that which they objectify through the very act of writing, can be quite poignant if the object of writing is the 'self' itself. Extending this thought, if one were to read selfwriting as a confession, then students' writing could become an opportunity not only to give life to what is narrated, but to re-script the self. Such a concept has yet to find its place in the conceptualisation of academic writing and voice. How would one describe the emerging self in students' writing?

Perhaps, this self bears similarities with what Biko might have meant when he referred to the 'envisioned self' (Biko 1987:49). Biko states that the 'envisioned self' is the 'liberated self' that has 'rid [himself] of the shackles that bind [him] to perpetual servitude'. These shackles could also be mental ones, such as hegemonic discourses that reproduce themselves through blind compliance.

Ācknowledging Reflective writing as a (discomforting) confession

\section{Reflective writing as a confession}

Writing about the discipline

Form of control

Compliance

(Ässimilation)

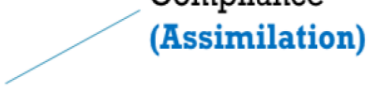

Practice of

freedom

(Disruption)
Writing the discoursal self, and authorial self*

Writing about the self (autobiographical self)

Writing and re-writing the 'envisioned self' (Biko) 
In their reflections, if students merely regurgitated theories without bringing themselves to the fore, they would fall in the first category of compliance. They would write about the discipline and perform an expected discoursal self.

Their writing could also have moments of the authorial self. By this, we mean a critical self that takes ownership of ideas. It could be claimed that the authorial self should feature in the other category of practice of freedom. However, we argue that academia values a very specific type of authorial self that requires students to master logical reasoning, rather than draw on other aspects of persuasion, such as ethics or emotions. Therefore, we would place the authorial self within the assimilation category.

On the other hand, and that is part of the practice of freedom, if students use the reflective story to share their life experiences, then their writing may have more of the autobiographical self.

\section{The Envisioned Self in Writing}

In light of the data, especially within a pedagogy of discomfort, we are beginning to see the emergence of a fourth writing self, which we now call the 'envisioned self' using Biko's terminology, to signal a disposition that transcends the fixation on logos in academia, to acknowledge modes of ethical validation. This constitutes a key finding for this study for it assists us in stretching our conceptualisation of writer identities and theorising a new disposition that we are witnessing in students' writing.

Thus, we propose adding a fourth leaf to Clark and Ivanic's (1997) clover model.

The envisioned self can be defined as the expression of an ethical and often socio-political stance adopted by students as they critically reflect on their positionality in relation to the course, the institution and society. The envisioned self operates not only within the course, but through and beyond the course. It spirals outward to urge one to reflect on one's location within the institutional spaces as these are part and parcel of forms of control seeking compliance, and beyond. The envisioned self prompts one to reflect on how the course may shift one's sense of self and view of the world. It invites one to negotiate one's sense of belonging through writing, to reflect on what aspects of one's being to keep and what to discard, to reflect on diversity, on the curriculum, and to use one's narrative to respond to or write back to the academy and its dominant norms where necessary. 


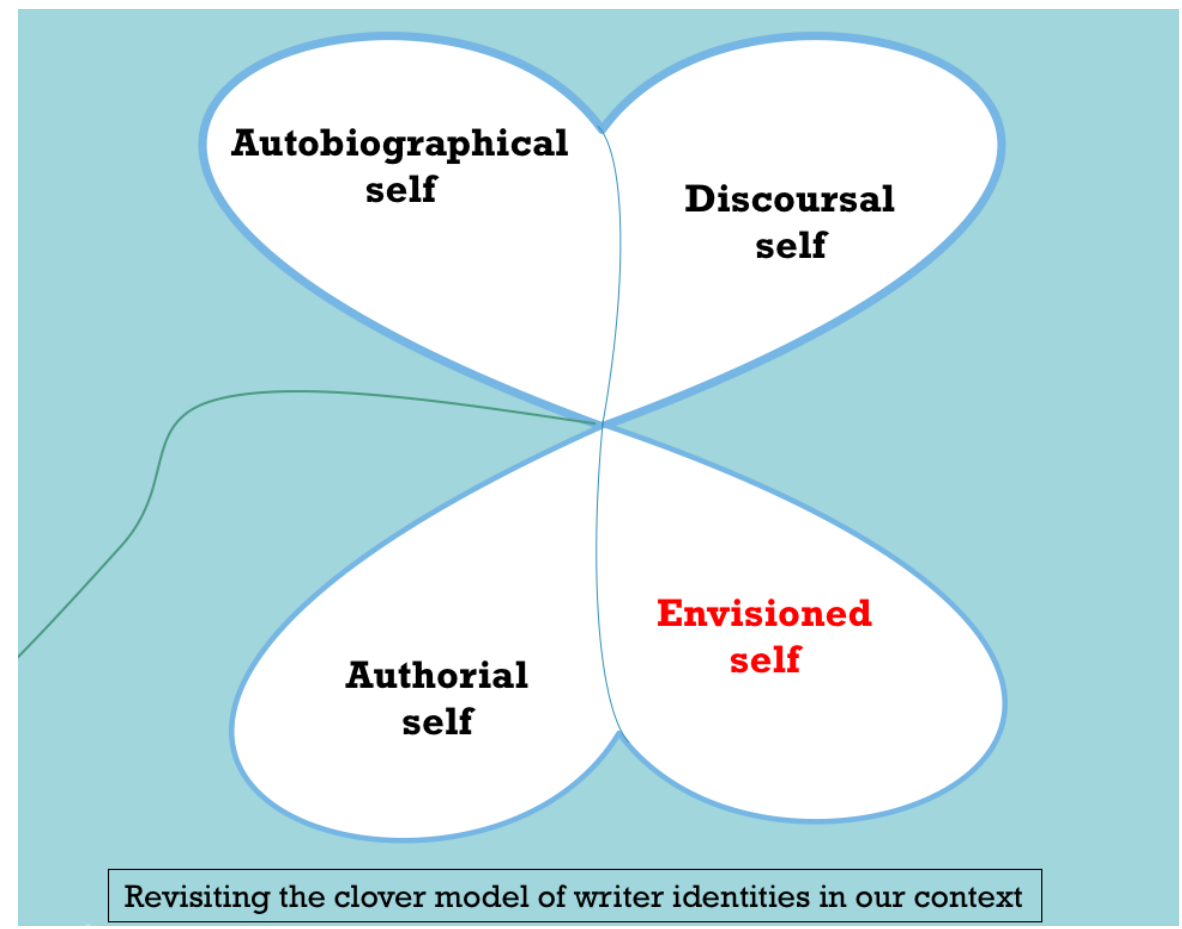

So, the envisioned self is a reflective past looking self, and it is also an aspirational, future-looking self that turns writing into a commentary on one's context and a tangible record of one's outlook, as it has been stabilised for now. Both the reflective past-looking self and aspirational future-looking self is anchored in the present by the creation of disruptive/discomforting moments which act as a stimulus for the types of past and future reflections alluded to here!

By using students' reflections as lenses to view ourselves as lecturers, we can begin to reflect on our practices and how we envision ourselves, and our roles.

\section{Implications for Writing Pedagogies}

Writing tasks that create allowances for ethical modes of expression to exist alongside the cognitive modes, could raise the complexity of students' 
engagement with academic texts and concepts beyond the confines of the formal curriculum.

In our view, the revisited clover model could apply to academic essays as well. Still, the expansion of available writing repertoires to incorporate hitherto invisible aspects of one's writer identities could enable us to sharpen the indexical links between the academic texts that students produce and the socio-political context that surrounds them, in contrast to traditional writing modes that sometimes remain self-referential. The new writing repertoires within academia could also create possibilities for students and lecturers to speak back to issues of social and epistemic access, and the inevitable tensions between them.

Generally, what gets viewed as social access is access to institutional spaces, dominant norms and practices, and what gets implied by epistemic access is access to available and acceptable subject positions within academia. In some students' reflections, epistemic access gives them the language to articulate what they previously struggled to pin down, and in that sense, to create some coherence out of multiple incoherent understandings of the self (Dugdale, 1999). In other reflections, we note some apprehension around the fact that the cultivation of an epistemic gaze may uproot them from their community selves and related dispositions.

In response, the reflective moments create a space for students to hold the social and epistemic dimensions in a state of productive tension. For lecturers, the reflective moments could become spaces to be critically aware of how we enforce or help negotiate various forms of access. Those moments could get us to pause and ask ourselves what kind of knowledge we are granting epistemic access to, and to confront the artificial divide between the social and the epistemic dimensions, to open avenues for an envisioned self in writing that mediates as well as interrogates both.

\section{Conclusion}

To conceive of writing as a confession creates possibilities to imagine to new kind of student writer, that chisels new personas as he crafts new scripts. Engaging with our students' narratives serves as a reminder for us to be vigilant of our own locations within a previously white university space, and the ways in which we may have been co-opted into certain dominant discourses that continue to add to our students' sense of marginalisation. Students' confessions 
are part of the discomfort that we as lecturers need to engage in with our students, in order to remain responsive to the dilemmas which present themselves in the ECP classroom so that possibilities for change remain within reach.

As ECP lecturers, we are primarily practitioners in the field, and we view this role as an opportunity rather than a deficit, as it opens avenues for authentic learning, whereby practice leads to theory.

What the research process has enabled us to do is to articulate for ourselves, to confess and name what our writing pedagogy looks like and what it entails for both parties. It also enabled us to theorise a particular form of writer identity, the 'envisioned self', which opens avenues for the writer's ethical stance to be constructed, expressed and critiqued through writing. It became necessary to name this feature of writer identity to legitimise the modes of expression that did not neatly fit the a priori model of writer identities.

\section{References}

Adichie, C. 2016. Transcript of 'The Danger of a Single Story'. [online] Ted.com. Available at:

https://www.ted.com/talks/chimamanda adichie the danger of a singl e_story/transcript?language $=$ en (Accessed on 1 February 2017.)

Arend, M., A. Hunma, C. Hutchings \& G. Nomdo 2017. The Messiness of Meaning Making: Examining the Affordances of the Digital Space as a Mentoring and Tutoring Space for the Acquisition of Academic Literacy. Journal of Student Affairs in Africa. 5:89 - 111. https://doi.org/10.24085/jsaa.v5i2.2704

Biko, S. 1978. I write what I like: A Selection of his Writings. Stubbs, A (ed.). Johannesburg: Heinemann.

Blommaert, J. 2005. Discourse: A Critical Introduction. Cambridge University Press. https://doi.org/10.1017/CBO9780511610295

Boler, M. \& M. Zembylas 2003. Discomforting Truths: The Emotional Terrain of Understanding Difference. In Trifonas, P. (ed.): Pedagogies of Difference: Rethinking Education for Social Change. New York: RoutledgeFalmer.

Bozalek, V. \& R. Carolissen 2012. The Potential of Critical Feminist Citizenship Frameworks for Citizenship and Social Justice in Higher Education. Perspectives in Education. 30:9 - 18. 
Aditi Hunma, et al.

Bozalek, V. \& M. Zembylas 2017. Towards a Response-able Pedagogy across Higher Education Institutions in Post-apartheid South Africa: An Ethicopolitical Analysis. Education as Change 21, 2: 62 - 85.

https://doi.org/10.17159/1947-9417/2017/2017

Clark, R. \& R. Ivanic 1997. The Politics of Writing. Hoboken: Taylor and Francis.

Creswell, J.W. 2013. Qualitative Inquiry \& Research Design: Choosing among Five Approaches. $3^{\text {rd }}$ Edition. Thousand Oaks, Sage.

Davis, R. \& M. Shadle 2000. 'Building a Mystery': Alternative Research Writing and the Academic Act of Seeking. College Composition and Communication 51, 3: 417 - 446.

https://doi.org/10.2307/358743

Deleuze, G. \& F. Guattari 1987. A Thousand Plateaus: Capitalism and

Schizophrenia. Minneapolis: University of Minnesota Press.

Dugdale, A. 1999. Materiality: Juggling Sameness and Difference. The Sociological Review 47:113 - 135.

https://doi.org/10.1111/j.1467-954X.1999.tb03485.x

Fraser, N. 2005. Reframing Justice in a Globalizing World. New Left Review $36: 69-88$.

Foucault, M. 1984. The Ethics of the Concern for Self as a Practice of Freedom.

Interview by H. Becker et al. In Rabinow, P. (ed.): Ethics: Subjectivity and Truth. New York: The New Press.

Foucault, M. 1990. The History of Sexuality: An Introduction. New York: Vintage Books.

Foucault, M. 1983. Self Writing. Translated from Corps écrit no 5: 3 - 23.

Available at: https://foucault.info/documents/foucault.hypomnemata.en/

Law, J. 2002. Aircraft Stories: Decentering the Object in Technoscience.

Durham, NC: Duke University Press.

https://doi.org/10.1215/9780822383543

Hunma, A. 2009. Identity and Coping Strategies in Academic Writing: A Study of First Year Mauritian Students at a South African University [Thesis]. University of Cape Town. Available:

https://open.uct.ac.za/bitstream/handle/11427/8277/thesis_hum_2009_h unma a.pdf?sequence $=1$ \&isAllowed $=\mathrm{y}$

Hyland, K. 2002. Authority and Invisibility: Authorial Identity in Academic Writing. Journal of Pragmatics 34, 8: 1091 - 1112. https://doi.org/10.1016/S0378-2166(02)00035-8 
Matsuda, P.K. 2001. Voice in Japanese Written Discourse: Implications for Second Language Writing. Journal of Second language writing 10, 1-2: 35 - 53. https://doi.org/10.1016/S1060-3743(00)00036-9

Mbembe, A. 2016. Decolonizing the University: New Directions. Arts \& Humanities in Higher Education 15, 1:29 - 45.

https://doi.org/10.1177/1474022215618513

Morrow, W. 2009. Bounds of Democracy: Epistemological Access in Higher Education. Cape Town: HSRC Press.

Ngugi wa Thiong'o. 1987. The Language of African Literature. In Decolonising the Mind: The Politics of Language in African Literature. Harare: Zimbabwe Publishing House.

Park, G. 2013. 'Writing is a way of knowing': Writing and Identity. Elt Journal $67,3: 336-345$.

https://doi.org/10.1093/elt/cct012

Pratt, M.L. 1991. Art in the Contact Zone. Profession 33 - 40.

Prebel, J. 2016. Engaging a 'Pedagogy of Discomfort': Emotion as Critical Inquiry in Community-Based Writing Courses. Composition Forum 34, Summer.

Samson, S., M. Arend, C. Hutchings, A. Hunma \& G. Nomdo 2018. Constructing the ECP Lecturer through an Analysis of Student Reflective Essays. In Teaching in Extended Programmes in South Africa: Classroom Contexts, Lecturer Identities and Teaching Practices. Fundani CHED. Cape Town: CPUT.

Scott, I. 2017a. Without Success, Access will Fail. In Mail \& Guardian Online, October $6^{\text {th }}$. Available at: https://mg.co.za/article/2017-10-06-00-withoutsuccess-access-will-fail (Accessed on 16 October 2018.)

Scott, I. 2017b. Core Issues besides Finance and Access Hinder Students' Success. In Mail \& Guardian Online, October $20^{\text {th }}$. Available at: https://mg.co.za/article/2017-10-20-00-core-issues-besides-finance-andaccess-hinder-students-success (Accessed 27 July 2018.)

St Pierre, E.A. 2017. Writing Post Qualitative Inquiry. Qualitative Inquiry 9,24:1 - 6. https://doi.org/10.1177/1077800417734567

Stake, R.E. 1995. The Art of Case Study Research. Thousand Oaks: Sage Publications.

Wilson-Strydom, M. 2011. University Access for Social Justice: A Capabilities Perspective. South African Journal of Education 31:407 - 418. https://doi.org/10.15700/saje.v31n3a544 
Aditi Hunma, et al.

Yin, R.K. 2014. Case Study Research: Design and Methods. Los Angeles: Sage.

Zembylas, M. 2015. 'Pedagogy of Discomfort' and its Ethical Implications: The Tensions of Ethical Violence in Social Justice Education. Ethics and Education 10:163 - 174.

https://doi.org/10.1080/17449642.2015.1039274

Zembylas, M. \& M. Boler 2002. On the Spirit of Patriotism: Challenges of a 'Pedagogy of Discomfort'. Teachers College Record August 12.

Aditi Hunma

Language Development Group, ADP, CHED

University of Cape Town aditi.hunma@uct.ac.za

Moeain Arend Language Development Group, ADP, CHED

University of Cape Town moeain.arend@uct.ac.za

Gideon Nomdo Language Development Group, ADP, CHED University of Cape Town gideon.nomdo@uct.ac.za

Catherine Hutchings Language Development Group, ADP, CHED

University of Cape Town catherine.hutchings@uct.ac.za

Sean Samson

Language Development Group, ADP, CHED

University of Cape Town

sp.samson@uct.ac.za 